\title{
PENGIDENTIFIKASIAN HURUF HIJAIYAH YANG BENTUKNYA SAMA SEBAGAI STRATEGI PENINGKATAN MOTIVASI DAN KEBERHASILAN MEMBACA IQRO' PADA SISWA SDLB TUNAGRAHITA RINGAN (C)
}

\author{
Fitriyah Rohmatin $^{78}$
}

SLB BHAKTI KENCANA BERBAH SLEMAN DIY

Email: fitrysafitry73@yahoo.com

\begin{abstract}
ABSTRAK
Penelitian ini bertujuan untuk mengetahui efektivitas pengidentifikasian huruf hijaiyah yang bentuknya sama dengan menggunakan kartu bertulisan huruf hijaiyah dan papan panel sebagai strategi peningkatan motivasi dan keberhasilan membaca Iqro’ bagi siswa SDLB tunagrahita ringan (C) Bhakti Kencana Berbah, Sleman, Yogyakarta.
\end{abstract}

Penelitian ini merupakan kolaboratif. Setting penelitian yang dipilih adalah di dalam/ di luar kelas pada jam pelajaran Pendidikan Agama Islam kelas III yang terdiri dari 4 siswa.

Langkah-langkah penelitian ini mencoba menggunakan model desain yang dikembangkan oleh Kemmis \& MC. Taggert yang terdiri empat tahap yang meliputi perencanaan, tindakan, pengamatan, dan refleksi. Keempat tahapan ini sebagai untaian dalam satu siklus. Adapun alat monitoring menggunakan observasi kelas, catatan lapangan, untuk evaluasi dapat diketahui dari proses dan hasil pembelajaran. Analisis data yang digunakan adalah analisis deskriptif non statistik. Adapun penelitian dibagi menjadi dua siklus. Pada siklus I pembelajaran huruf hijaiyah belum memperoleh hasil yang maksimal, sebagai bukti siswa-siswa kurang semangat, masih keliru/terbalik dalam melafadzkan beberapa huruf hijaiyah, hal ini karena ada beberapa hal yaitu: 1. Pada siklus I dalam mengenalkan huruf hijaiyah disertai huruflatinnya, dalam pengenalan hurufhijaiyah diurutkan, sehingga apabila diacak siswa sering kebalik. 2. Papan panel yang digunakan hanya satu dipasang dipapan tulis, sehingga anak sering berebutan untuk maju, hal ini mengganggu proses pembelajaran.

Berdasarkan hasil evaluasi siklus I, peneliti mengadakan perbaikan pada siklus ke II antara lain: 1). Dalam pengenalan huruf hijaiyah tanpa disertai huruf latinnya, dalam membaca huruf hijaiyah tidak diurutkan/ diacak, tetapi membacanya sesuai kelompok huruf yang bentuknya sama dan diulang-ulang sampai siswa paham.

78 Guru Pendidikan Agama Islam (PAI) SLB Bhakti kencana Berbah Sleman DIY

AL-BIDAYAH: Jurnal Pendidikan Dasar Islam Volume 9, Nomor 1, Juni 2017; ISSN: 2085-0034 
2). Saat membaca direkam, setelah selesai bisa mendengarkan suaranya sendiri, sehingga siswa mengetahui pelafadzan yang belum benar. 3). Alat Bantu yang digunakan disiapkan sesuai jumlah siswa, sehingga siswa tidak berebutan, bagi siswa yang belum mendapat giliran bisa mencoba sendiri di mejanya masingmasing. Untuk melatih motorik, siswa yang sudah mendapat giliran, mendapat tugas untuk menyalin materi yang telah dipelajari. Sehingga dalam siklus ke II ini pembelajarannya lebih kondusif, siswa lebih senang, perhatian, semangat, sebagai bukti siswa sudah mampu membaca huruf hijaiyah dan mampu menyelesaikan Iqro' jilid I dengan benar dan lancar dan mulai Iqro'II. Berdasarkan hasil yang diperoleh bahwa pengidentifikasian huruf hijaiyah yang bentuknya sama dengan alat Bantu karton yang bertulisan huruf hijaiyah dan papan panel, walaupun alat tersebut sederhana, dapat meningkatkan keberhasilan membaca huruf hijaiyah/ Iqro' bagi siswa SDLB III SLB C Bhakti Kencana Berbah Sleman, Yogyakarta.

Kata kunci: Identifikasi huruf hijaiyah, Motivasi, hasil belajar Iqro'

\begin{abstract}
This study aims to determine the effectiveness of identification of hijaiyah letters in the same form using hijaiyah lettered cards and panel boards as a strategy to increase the motivation and success of reading Iqro'for students of SDLB tunagrahita light type (C) Bhakti Kencana Berbah, Sleman, Yogyakarta.

This research is collaborative. The selected research setting is inside/ outside the classroom during the third grade Islamic Education class consisting of 4 students. The steps of this research are trying to use the design model developed by Kemmis \& MC. Taggert consists of four stages that include planning, action, observation, and reflection. These four stages are as threads in one cycle. The monitoring tool uses classroom observation, field notes, for evaluation can be known from the process and learning outcomes. Data analysis used is non statistical descriptive analysis. The study is divided into two cycles. In the first cycle of learning hijaiyah letters have not obtained maximum results, as evidence of students lack of spirit, is still mistaken / reversed in spelling some letters hijaiyah, this is because there are several things: 1. In cycle I in introducing letters hijaiyah accompanied by Latin letters, In the introduction of hijaiyah letters sorted, so that if the random students are often reversed. 2. Panel board used only one installed on the floor, so children often scramble to move forward, this disrupts the learning process.

Based on the results of the evaluation cycle I, the researchers make improvements in the second cycle, among others: 1). In the introduction of letters hijaiyah without the Latin letters, in reading hijaiyah letters are not sorted/ randomized, but read it according to groups of letters of the same shape and repeated until students understand. 2). When reading recorded, when finished can listen to his own voice, so
\end{abstract}


that students know that spelling is not yet true. 3). Tools used are prepared according to the number of students, so students do not scramble, for students who have not got a turn can try on their own table. To train their motoric, students who have got a turn, got the task to copy the material that has been studied. So in the second cycle this learning is more conducive, the students are more happy, the attention, the spirit, as proof the students have been able to read the hijaiyah letter and able to finish Iqro' I correctly and smoothly and start Iqro' II. Based on the results obtained that the identification of the hijaiyah letters that are similar in form to the carton-assisted tool with the letter hijaiyah and the panel board, although the tool is simple, can improve the success of reading hijaiyah/Iqro'for the students of SDLB III SLB C Bhakti Kencana Berbah Sleman, Yogyakarta.

\section{Keywords: Identification of hijaiyah letter, Motivation, learning result Iqro'}

\section{A. PENDAHULUAN}

Mengenal, melafadzkan, dan mampu menghafal surat-surat pendek dalam Alqur'an, do'a sehari-hari bagi anak sangat penting, Karena Alqur'an merupakan fondasi pengajaran bagi kurikulum PAI dan merupakan salah satu "Syiar ad-diin" yang menguatkan aqidah dan mengokohkan keimanan. Untuk mempermudah menghafal do'a sehari-hari, mampu membaca Iqro' (Alqur'an) adalah sangat penting dan menjadikan Alqur'an sebagai bacaan seharihari, otomatis aqidah akan mengalir dan tertanam kokoh dalam qolbunya. Inilah pentingnya menanamkan kecintaan dan kemampuan membaca huruf Alqur'an bagi anak-anak SLB C sedini mungkin. Hal ini sesuai dengan "asy-syiasah"nya Ibnu Sina untuk mengajarkan Alqur'an. Al-qur'an harus mendapatkan prioritas pertama untuk diajarkan kepada anak.

Dalam pembelajaran Iqro’ di SLB C belum menunjukkan hasil yang maksimal. Hal ini disebabkan beberapa faktor baik intern maupun ekstern. Faktor intern berhubungan dengan keadaan anak, baik minat, motivasi maupun kemampuannya, karena permasalahan anak Tunagrahita sangat komplek. Hal ini sesuai dengan pendapat AA. Branata yang dikutip Sutratinah Tirtonegoro (1997: 3), bahwa anak Tunagrahita ringan adalah anak yang mengalami hambatan dalam perkembangan dan pertumbuhan mental di bawah normal, sehingga memerlukan bimbingan khusus, agar mentalnya dapat berkembang sesuai potensi yang dimilikinya.

Selain faktor intern tersebut di atas, juga disebabkan faktor ektern diantarannya berkaitan dengan strategi yang digunakan dalam pembelajaran. Menyadari adannya beberapa faktor yang menjadi kurang berhasilnya dalam pembelajaran Iqro', maka perlu dikaji faktor utama yang dihadapi anak didik dalam proses pembelajaran Iqro', yaitu perlu adanya strategi yang menarik dan sesuai bagi anak dalam pembelajaran pendidikan agama Islam, khususnya dalam pembelajaran iqro'. Hal ini juga terjadi pada anak-anak Tunagrahita ringan SLB C Bhakti Kencana Berbah, Sleman, Yogyakarta.

Dalam pembelajaran Iqro' di SLB C kelas III belum menunjukkan hasil yang maksimal, sebagai bukti siswa sulit membedakan huruf yang bentuknya sama tetapi berbeda tandanya, apabila huruf tersebut muncul tidak bersamaan. 
Contohnnya:
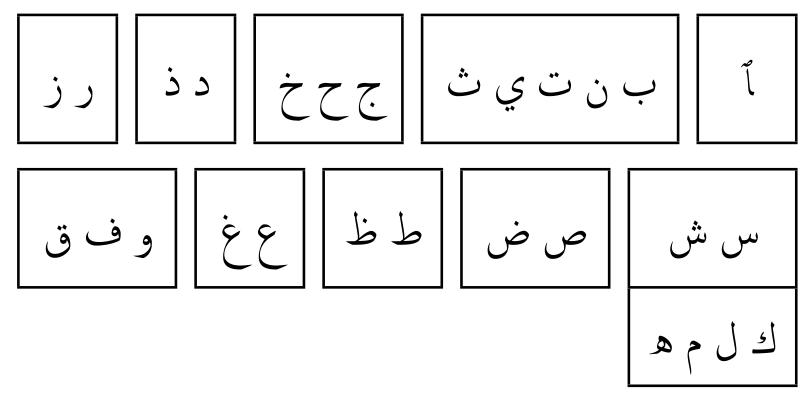

Hal ini karena anak Tunagrahita ringan sulit berkonsentrasi, mudah lupa dan bosan, sehingga dalam pembelajaran iqro' anak tidak sekadar mendengar dan melihat, tetapi siswa perlu mempraktikkan langsung. Untuk itu perlunya strategi dan alat bantu/ alat peraga yang menarik dalam pembelajaran.

Berdasarkan latar belakang di atas maka permasalahan yang muncul dapat dirumuskan, "Bagaimanakah pelaksanaan strategi pengidentifikasian huruf hijaiyah yang sama bentuknya dengan kertas karton bertulisan huruf hijaiyah dan papan panel sebagai alat bantu dapat meningkatkan keberhasilan membaca Iqro' pada siswa kelas III SDLB Tunagrahita ringan $(\mathrm{C})$ ".

Tujuan yang akan dicapai dalam penelitian adalah untuk mengatasi kelemahan siswa Tunagrahita ringan dalam pembelajaran Iqro', mengetahui keberhasilan pembelajaran Iqro' siswa Tunagrahita ringan dengan strategi pengidentifikasian huruf hijaiyah yang bentuknya sama dengan karton yang bertulisan huruf hijaiyah dan papan panel sebagai alat bantu.

\section{Anak Tunagrahita Ringan}

Anak tunagrahita ringan adalah anak yang mengalami kekurangan atau tidak berfungsinya organ tertentu pada otak atau syaraf yang terjadi pada usia perkembangannya, sehingga secara umum terjadi hambatan kemampuan intlektual, IQ berkisar antara 50/55-70/75 (Setia P, 2005: 12). Agar potensi yang dimilikinya dapat berkembang secara maksimal maka perlu bimbingan dan pelayanan khusus.

\section{Strategi Pembelajaran}

Strategi dapat diartikan sebagai Plan, Method, atau series of activies designed to achievies a particular educational goal (J. R. David, 1976), yaitu merupakan tindakan (rangkaian tindakan) yang didesain untuk mencapai tujuan.

Menurut Wina Sanjaya, pembelajaran merupakan kegiatan yang bertujuan yaitu membelajarkan siswa yang merupakan rangkaian kegiatan yang melibatkan berbagai komponen antara lain: guru, siswa, metode, materi, sarana dan prasarana, lingkungan.

Dari pendapat di atas disimpulkan bahwa yang dimaksud strategi adalah suatu upaya yang dilakukan agar pembelajaran dapat berhasil dengan baik, yaitu terbangunnya motivasi dan kemampuan mengenal dan membaca iqro' dengan benar dan lancar.

\section{Membaca Iqro'}

Materi pembelajaran Alqur'an terdiri dari iqro' jilid 1- 6, mulai pengenalan huruf hijaiyah, cara pelafadzan sampai mampu membaca Alqur'an dengan benar. Membaca Iqro' di SLB C Bhakti Kencana merupakan bagian materi pendidikan agama Islam, yang berisi tentang pengetahuan pengenalan huruf hijaiyah atau membaca Alqur'an permulaan (materinya iqro' jilid I). Adapun contoh pengelompokan hurufnya sebagai berikut. 


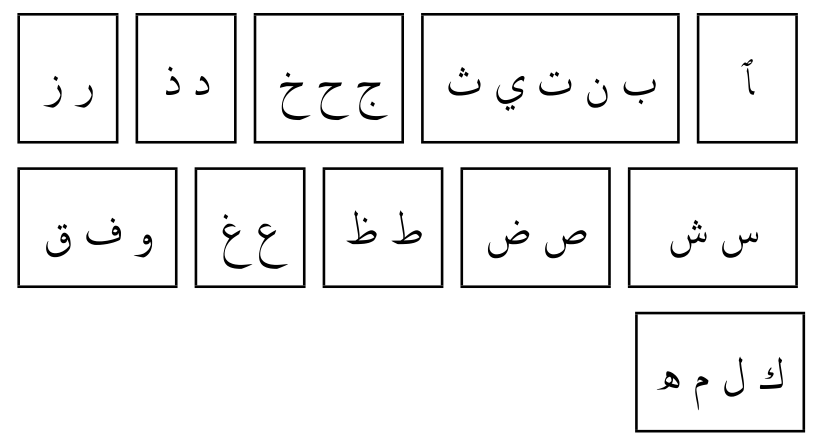

4. Langkah Dalam Membaca Iqro'

1. Pengenalan huruf hijaiyah yang sama bentuknya dengan harokatnya disertai huruf latinnya.

2. Memberi contoh cara melafadzkan huruf hijaiyah yang bentuknya tetapi pelafadzannya hampir sama, misalnya:

\begin{tabular}{|c|c|}
\hline س - ث & $\varepsilon-i$ \\
\hline ث - ش & $\tau^{-\infty}$ \\
\hline س - ش & $j-ج$ \\
\hline س ص & ي - ز \\
\hline ت - & $\dot{\varepsilon}-\dot{z}$ \\
\hline ذ - ظ & ق \\
\hline ظ - ض & $\ddot{\theta}-\dot{q}$ \\
\hline
\end{tabular}

\section{B. METODE PENELITIAN}

\section{Pendekatan}

Pendekatan yang digunakan dalam penelitian ini adalah pendekatan tindakan kelas, yang merupakan penelitian praktis yang dilakukan di kelas yang bertujuan untuk memperbaiki dan meningkatkan kualitas pembelajaran yang ada. Dalam penelitian ini adalah untuk meningkatkan kemampun dalam pembelajaran Iqro'.

\section{Setting dan Waktu Penelitian}

Setting penelitian ini adalah siswa SDLB C kelas III SLB Bhakti Kencana, pelaksanaannya pada jam pembelajaran pendidikan agama Islam berlangsung, baik di dalam kelas maupun di luar kelas (masjid). Setting ini disesuaikan dengan rencana tindakan peneliti untuk melaksanakan proses refleksi, analisis, dan evaluasi dalam pembelajaran membaca Iqro'. Waktu penelitian sampai pembuatan laporan selama tiga bulan, yaitu dimulai bulan FebruariOktober 2015.

\section{Lokasi dan Subjek Penelitian}

Penelitian dilakukan di SLB C Bhakti kencana Berbah Sleman Yogykarta. Dalam pelaksanaannya penelitian melibatkan sejumlah siswa kelas III SDLB C dan kolaborator. Pertemuan antara peneliti dengan kolabolator, mendiskusikan tindakan penelitian, yang kemudian disepakati dilakukannya tindakan tertentu untuk meningkatkan keberhasilan membaca Iqro’.

\section{Metode dan Alat Monitoring Dalam Pengumpulan Data}

Penelitian ini menggunakan tehnik dan alat monitoring yang meliputi:

a. Observasi

Yaitu pengumpulan data untuk mengetahui respon dan motivasi siswa dan aktivitas guru saat pembelajaran Iqro' Observasi yang dilaksanakan meliputi implementasi dalam kegiatan monitoring tentang proses belajar mengajar, proses tindakan, pengaruh tindakan terhadap keberhasilan pembelajaran. Hasil observasi yang dilaksanakan meliputi implementasi dalam kegiatan monitoring tentang proses belajar mengajar, proses tindakan, pengaruh tindakan terhadap keberhasilan pembelajaran Iqro'. Hasil observasi yang dilakukan oleh tim 
kemudian diintepretasikan.

b. Tes

Menurut Suharsimi Arikunto (2002: 127) tes adalah serentetan pertanyaan yang digunakan untuk mengukur keterampilan, pengetahuan, intelegensi dan bakat yang dimiliki oleh individu atau kelompok. Tes dalam penelitian ini adalah untuk mengetahui kemampuan membaca Iqro', baik secara lisan maupun tertulis. Data yang diperoleh berbentuk kuantitatif maupun kualitatif.

c. Wawancara

Yaitu suatu metode untuk mendapatkan informasi tentang kondisi siswa baik langsung dengan siswa, guru kelas maupun wali murid. Alat yang digunakan adalah panduan yang telah dipersiapkan. Wawancara terfokus yang berhubungan dengan kegiatan pembelajaran Iqro', sehingga dapat menjadi masukan pada pembelajaran selanjutnya.

d. Dokumentasi

Adalah suatu metode untuk mengungkap dan menyimpan suatu data, dalam penelitian ini mengumpulkan data yang berkaitan dengan siswa dan pengambilan foto dalam pembelajaran dengan menggunakan kamera.

\section{Prosedur Pelaksanaan Tindakan}

Prosedur dalam pelaksanaan penelitian ini adalah sebagai berikut.

a. Perencanaan

Untuk meningkatkan kemampuan membaca Iqro' siswa kelas III, yaitu dengan strategi pengidentifikasian huruf hijaiyah yang bentuknya sama dengan menggunakan karton dan papan panel yang bertuliskan huruf hijaiyah, penayangan menggunakan LCD, pada saat pembelajaran berlangsung. Penelitian tindakan kelas ini dilakukan untuk mengatasi permasalahan yang dihadapi di kelas pada pembelajaran membaca Iqro'. Adapun langkah-langkah penelitian ini menggunakan model desain yang dikembangkan oleh Kemmis \& Mc Taggart (1990) yang terdiri dari empat komponen, yang meliputi perencanaan, tindakan, pengamatan, dan refleksi. Keempat komponen ini sebagai untaian dalam satu siklus. Dalam penelitian ini terbagi menjadi dua siklus tindakan dan setiap tindakan dilakukan observasi/ pengamatan secara kolaboratif.

Kegiatan yang dilakukan pada tahap ini adalah: 1) Peneliti mengadakan pertemuan dengan kolabolator untuk melakukan identifikasi tentang permasalahan yang muncul, berkaitan dengan pembelajaran huruf hijaiyah (Iqro'); 2). Merancang pelaksanaan pemecahan masalah; 3) peneliti dan kolabolator mendiskusikan rencana tindakan yang akan akan dilakukan.

Pada tahap ini langkah-langkahnya antara lain:

Membuat rencana pembelajaran yang berisi langkah-langkah yang dilakukan guru dan murid dalam pembelajaran Iqro', yang meliputi kegiatan awal/ apersepsi, kegiatan inti, kegiatan akhir (evaluasi). Adapun skenario pembelajaran pada siklus pertama sebagai berikut.

1. Siswa masuk kelas/ masjid dan duduk di tempat masing-masing.

2. Guru membuka pelajaran, kemudian bersama-sama siswa melafadzkan do'a sebelum belajar. 
3. Guru menyiapkan karton dan papan panel yang bertuliskan huruf hijaiyah sesuai materi yang akan disampaikan.

4. Guru mengenalkan huruf hijaiyah sesuai dengan materi yang akan disampaikan.

5. Guru memberi contoh melafadzkan huruf hijaiyah, siswa bersama-sama menirukan, kemudian melafdakan satu persatu secara bergantian.

6. Guru mendemonstrasikan huruf hijaiyah, mengenalkan tandanya serta pelafadzannya, siswa menunjuk hurufnya dan melafadzkannya dengan bimbingan guru.

7. Siswa maju satu persatu menunjuk huruf hijaiyah sesuai dengan perintah guru.

Pada siklus ini guru memperkenalkan huruf hijaiyah dengan tanda bacanya dengan mengidentifikasi huruf yang bentuknya sama disertai huruflatinnya/ bacaannya. Hal ini membantu siswa dalam membacanya. Pada siklus ini terdapat 4 kali pertemuan, pada jam pendidikan Agama Islam/ jam praktik.

8. Pada siklus kedua skenario pembelajarannya sama dengan siklus pertama, bedanya dalam pembelajarannya anak membaca huruf hijaiyah tanpa dibantu huruf latinnya, alat bantu dipersiapkan sesuai dengan jumlah siswanya dan siklus kedua ini anak mengulang beberapa materi siklus pertama yang pelafadzannya masih keliru dan penambahan/ peningkatan materi sampai anak menguasai Iqro' jilid I. b. Prasurvei dan survei

Prasurvai dilakukan pada SDLB C kelas III pada pembelajaran pelajaran agama Islam, subjek yang akan dijadikan penelitian dan bertujuan untuk mengetahui kondisi awal. Dari hasil pengamatan dalam pembelajaran Iqro', siswa masih sulit dan sering keliru melafadzkan huruf yang bentuknya sama. Pada kegiatan pembelajaran pendidikan agama islam khususnya pembelajaran huruf hijaiyah, diadakan pengamatan dan pencatatan hal-hal yang dianggap penting kaitannya dengan strategi pembelajaran Iqro'. Pada akhir pembelajaran wawancara dengan siswa berkaitan dengan strategi yang digunakan. Hasil pengamatan, catatan dan wawancara, akan di-cros check dengan observer yang lain (kolabolator) untuk menyusun refleksi, sehingga hasil refleksi akan dijadikan dasar membuat perencanaan

c. Implementasi Tindakan

Dalam kegiatan tindakan, peneliti dan kolabolator telah melakukan tindakan sesuai rencana yang telah ditetapkan dalam proses pembelajaran, yaitu menyiapkan karton dan papan panel yang bertuliskan huruf hijaiyah sesuai materi yang akan disampaikan. Setiap pertemuan anak dikenalkan 4-6 huruf hijaiyah, cara pembelajarannya siswa menirukan melafadzkan, membaca dengan bimbingan guru, sampai anak memahami materi tersebut. Sehingga dalam setiap siklus ini terdiri 4 kali pertemuan, setiap minggu 1 jam (jam praktik). Pada siklus kedua anak mengulang-ulang huruf hijaiyah sampai mampu melafadzkan dan membaca dengan benar, sehingga siklus 
kedua ini anak mampu membaca Iqro' jilid I dengan lancar.

\section{d. Evaluasi dan Refleksi}

Pada tahap ini peneliti dan kolabolator melakukan observasi, monitoring, dan evaluasi terhadap pelaksanaan tindakan yang telah dilakukan. Kriteria keberhasilan yang akan dicapai adalah kemampuan membaca Iqro' dengan benar. Hasil observasi kemudian dianalisis untuk mengetahui kekurangannya dalam pembelajaran Iqro'. Rencana tindakan selanjutnya disusun dan didiskusikan dengan kolaborator.

Untuk lebih jelasnya desain penelitian tindakan dalam penelitian ini mengacu pada desain penelitian model Kemmis dan McTaggart sebagai berikut.

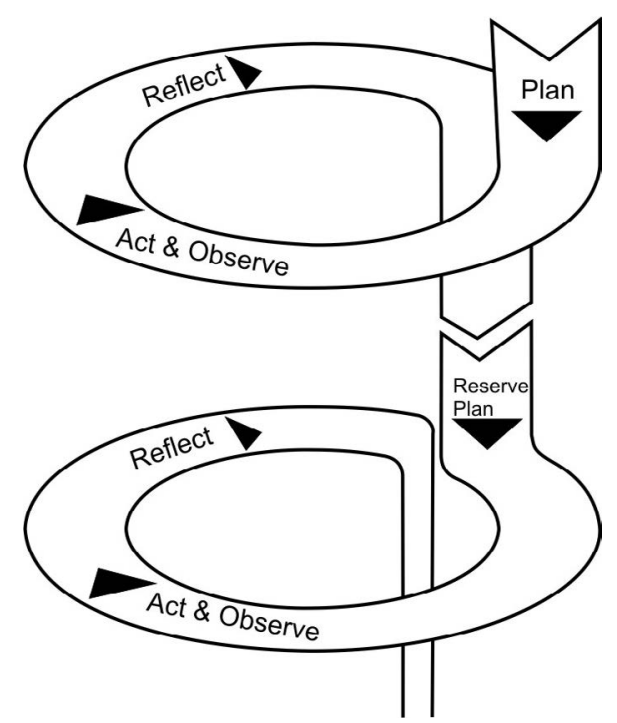

Gambar 1. Desain Tindakan

Keterangan :

Rencana tindakan dengan karton dan papan panel bertuliskan huruf hijaiyah dengan mengidentifikasi huruf hijaiyah, sesuai dengan materi yang akan diajarkan. Pelaksanaan tindakan, yaitu proses pembelajaran membaca huruf hijaiyah. Observasi pada waktu tindakan/ pembelajaran oleh tim peneliti. Refleksi, data dari observasi tersebut, direfleksi untuk rencana tindakan selanjutnya.

Pada prinsipnya refleksi adalah upaya analisis dan evaluasi yang dilakukan oleh peneliti dan kolabolator terhadap kegiatan tindakan untuk kemudian disimpulkan apakah perlu merencanakan kembali jenis tindakan berikutnya yang perlu diterapkan agar pembelajaran Iqro' lebih berhasil.

\section{Teknik Analisis Data}

Teknik analisis data adalah suatu usaha untuk menganalisis dan memberi interpretasi terhadap data yang terkumpul, baik yang berhubungan dengan siswa, strategi pembelajaran, maupun proses pembelajaranya. Dalam penelitian inipeneliti dalam menganalisis data menggunakan metode diskriptif non statistik. Adapun tahap-tahap analisis dalam penelitian ini sebagai berikut.

a. Reduksi data

Dalam tahap ini memilih data yang sudah masuk, diambil yang relevan dengan tujuan yang akan dicapai, mampu menjawab hipotesis yang telah ditetapkan.

b. Penyajian Data

Data yang diperoleh disajikan dalam bentuk laporan, bagan, grafik, dan narasi. Dalam penyajian data dibuat secara jelas, sehingga dapat dijadikan informasi yang mudah dipahami.

c. Menarik kesimpulan

Dalam membuat kesimpulan berdasarkan reduksi data yang telah masuk dan dianalisis. Kesimpulan adalah 
inti dari persiapan, proses, dan hasil yang diperoleh dalam pembelajaran, dalam hal ini adalah pembelajaran membaca Iqro’.

\section{PEMBAHASAN}

\section{Deskripsi Kemampuan Membaca Iqro'}

Sebelum peneliti mengadakan tindakan kepada subjek, untuk mengetahui kemampuan siswa membaca Iqro' diadakan pretest terlebih dahulu. Soal pretest dibuat oleh peneliti juga sebagai guru Agama Islam di kelas III SDLB C tersebut. Berikut disajikan hasil pretest kemampuan membaca Iqro’ siswa SDLB C III Tunagrahita Ringan.

\section{Data Kemampuan Membaca Iqro' (pretest)}
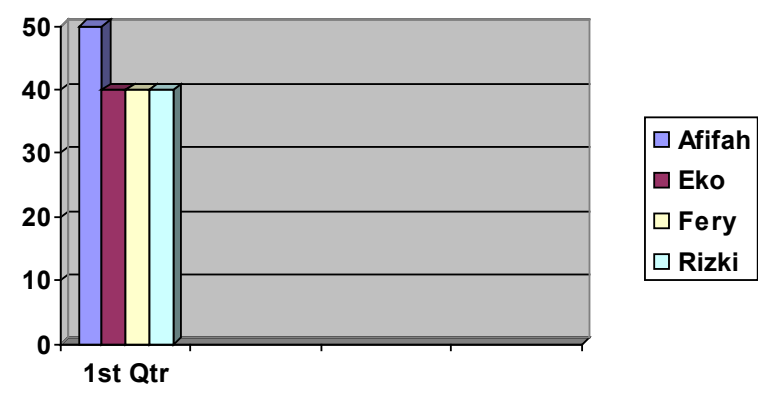

Dari pretest tersebut menunjukkan bahwa kemampuan membaca huruf hijaiyah antara siswa satu dengan yang lain berbedabeda.

\section{Deskripsi Pelaksanaan Tindakan Siklus I}

\section{a. Tahap Persiapan}

Pembukaan \pm 5 menit untuk mengkondisikan siswa dan berdo'a sebelum belajar, peneliti menyiapkan segala sesuatu yang berhubungan dengan pembelajaran Iqro'.

Adapun persiapan yang dilakukan adalah sebagai berikut.

1) Menyusun Silabus

Silabus disusun sebelum pembelajaran dilaksanakan dan disusun sesuai dengan kurikulum,standar kompetensi dan kompetensi dasar.

2) Membuat rencana program pembelajaran (RPP)

Rencana program pembelajaran dipersiapkan sebelum pembelajaran dan RPP ini merupakan rencana strategi pembelajaran juga berisi materi yang akan disampaikan pada setiap pertemuan yang mengacu pada silabus yang telah dibuat.

3) Menyiapkan strategi dan alat bantu pengajaran

Dalam penelitian tindakan kelas yang utama adalah menyusun strategi, yaitu dengan mengidentifikasi huruf hijaiyah yang bentuknya sama dalam pembelajaran Iqro' dan menyiapkan alat bantu pembelajarannya, yaitu tulisan huruf hijaiyah dengan menggunakan papan panel.

4) Menyusun jadwal pertemuan dan kegiatan setiap siklus

Kegiatan penelitian ini pelaksanaannya pada waktu pelajaran Pendidikan Agama Islam (jam praktik). Rencana pelaksanaan sebanyak dua siklus setiap siklusnya empat kali pertemuan. Adapun jadwal pelaksanaannya terlampir.

5) Membuat pedoman observasi/ pengamatan

Peneliti bersama tim menyusun pedoman pengamatan, agar dalam pengamatan lebih terarah dan memperoleh data sesuai yang diharapkan dalam penelitian ini. 
6) Menyiapkan alat dokumentasi gambar (kamera)

Dalam kegiatan penelitian, peneliti beserta tim menyiapkan kamera yang digunakan untuk mengambil gambar/ dokumentasi pada saat pembelajaran, hal ini sangat membantu dalam analisis data/ pengamatan.

\section{b. Tahap Pelaksanaan}

1) Pertemuan pertama

Kegiatan untuk siklus I dimulai pada tanggal 22 Agustus 2015. Pelaksanaan diawali dengan menkondisikan siswa, berdo'a sebelum belajar yang dipimpin oleh salah satu subyek.Selanjutnya guru mengadakan appersepsi tentang materi yang akan disampaikan yaitu membaca Iqro', untuk menjajaki kemampuan siswa satu persatu disuruh untuk membaca huruf hijaiyah. Dari appersepsi tersebut dapat diketahui kondisi dan kemampuan subjek dalam membaca Iqro'. Subjek sudah mengenal beberapa huruf hijaiyah tetapi rata-rata masih belum benar dan sering terbalik pelafadzannya. Tetapi ada satu anak yang sudah cukup mampu dan sangat antusias, sehingga membuat teman yang lain lebih semangat dalam pembelajaran.

Kegiatan selanjutnya guru menyiapkan huruf hijaiyah yang sudah dikelompokkan sesuai dengan bentuknya dan papan panel. Guru mengenalkan nama huruf hijaiyah dan cara melafadzkan:

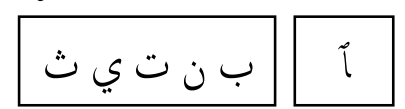

yang ditulis pada karton dan papan panel yang disertai tulisan latin dan tanda baca/ harakatnya. Peneliti menyebutkan nama huruf dan memberi contoh cara pelafadzannya, siswa menirukan bersama-sama, kemudian satu persatu secara bergantian, siswa memasang huruf hijaiyah pada papan panel atau alat bantu yang telah dipersiapkan sesuai dengan perintah/ instrupsi peneliti, juga dengan bimbingan peneliti. Pembelajaran Iqro' dengan mengelompokkan huruf yang bentuknya sama disertai alat bantu tersebut sangat berpengaruh dalam keberhasilan dalam pembelajaran Iqro'. Siswa lebih cepat paham karena di samping melafadzkan siswa juga mengerjakan/ aktif (terlihat dalam lampiran). Namun bagi siswa yang belum mendapat giliran sering ikut menjawab/ maju ke depan kelas, semua siswa ingin selalu diperhatikan, hal ini mengganggu siswa yang baru memasang huruf di depan/ mendapat tugas, sehingga siswa tidak bisa konsentrasi dan pembelajaran agak terganggu.

2) Pertemuan kedua

Pada tindakan siklus yang I (pertemuan kedua) tanggal 29 Agustus 2015, kegiatan awal, peneliti mengkondisikan siswa, mempersiapkan materi dan alat yang akan digunakan dan berdo'a sebelum belajar. Siswa membaca materi yang telah dipelajari sebelumnya secara bersama-sama kemudian membaca satu persatu dengan bimbingan peneliti, setelah anak benar-benar lancar dilanjutkan materi berikutnya.

Pada pertemuan kedua ini materinya adalah:

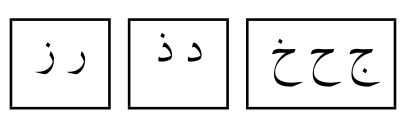

peneliti memberi contoh cara melafadzkan, siswa menirukan secara 
bersama-sama, kemudian satu persatu secara bergantian, sambil memasang huruf tersebut pada papan panel yang tela dipersiapkan. Pada pertemuan kedua ini anak lebih aktif dan lebih memahami materi yang disampaikan. Bagi yang sudah mendapat giliran membaca, diberi tugas untuk menyalin materi yang telah disampaikan dibuku tulis masing- masing, hal ini juga melatih motorik siswa.

Setelah selesai pembelajaran, diadakan posttest siswa membaca satu persatu untuk membaca materi yang telah dipelajari tanpa bantuan peneliti, rata- rata siswa sudah mampu membaca dengan benar, tapi masih ada siswa yang pelafadzannya masih keliru/ kebalik, dengan bimbingan peneliti dan mengulang-ulang ia mampu, agar siswa belajar di rumah maka guru memberi tugas/ pekerjaan rumah.

3) Pertemuan ketiga

Pertemuan ini dilaksanakan tanggal 6 September 2015. Kegiatan awal, peneliti menkondisikan siswa, mempersiapkan materi dan alat yang akan digunakan dan berdo'a sebelum belajar, siswa membaca materi yang telah dipelajari sebelumnya secara bersama-sama kemudian membaca satu persatu dengan bimbingan peneliti, setelah anak benar-benar lancar dilanjutkan materi berikutnya.

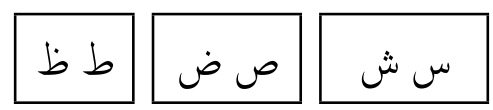

Guru menyebutkan nama huruf dan cara melafadzkan, siswa menirukan secara bersama-sama, kemudian satu persatu secara bergantian, sambil memasang huruf tersebut pada papan panel yang telah dipersiapkan. Pada pertemuan kedua ini anak lebih aktif dan lebih memahami materi yang disampaikan. Bagi yang sudah mendapat giliran membaca, diberi tugas untuk menyalin materi yang telah disampaikan dibuku tulis masing- masing. Hal ini juga melatih motorik siswa.

Setelahselesaipembelajarandiadakan posttest, siswa membaca satu persatu membaca materi yang telah dipelajari tanpa bantuan peneliti, rata- rata siswa sudah mampu membaca dengan benar, tapi masih ada siswa yang pelafadzannya masih keliru/ kebalik, dengan bimbingan peneliti dan mengulang-ulang ia mampu, guru memberi tugas/ PR.

4) Pertemuan keempat

Kegiatan pembelajaran dilaksanakan tanggal 13 September 2015. Kegiatan awal persiapan seperti pertemuan sebelumnya, guru menugaskan siswa untuk membaca materi sebelumnya/ pekerjaan rumah. Selanjutnya memasuki materi, kali ini mengenalkan huruf:

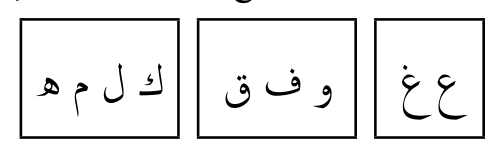

guru mencoba siswa untuk membacanya. Salah satu siswa ada yang sudah bisa, walaupun membacanya masih ada yang keliru/ kebalik. Kemudian guru mulai mengenalkan materi tersebut dengan menyebutkan nama huruf dan cara melafadzkannya. Siswa memperhatikan dengan semangat, menirukan secara bersama-sama, kemudian satu persatu membaca dengan bimbingan guru. Ada satu siswa yang sulit mengidentifikasi huruf, ia mudah lupa/ sering kebalik, sering ragu-ragu apabila diberi tugas membaca, tetapi dengan mengulangulang ia mampu membaca dengan cukup lancar. 
Kegiatan pembelajaran masih menggunakan tulisan huruf hijaiyah dan papan panel. Bagi siswa yang sudah mendapat giliran diberi tugas untuk menyalin materi yang telah disampaikan dibuku tulis masing-masing. Hal ini membuat anak senang dan tidak mudah bosan.

Pertemuan keempat ini diakhiri dengan posttest. Posttest kali ini materinya semua huruf hijaiyah yang sudah dipelajari, yaitu: أ -

Dari hasil posttest siswa sudah cukup lancar membaca, tapi masih ada beberapa huruf yang masih keliru membacanya/ melafadzkannya, sehingga masih perlu bimbingan lebih lanjut.

\section{c. Tahap monitoring}

Pada setiap tindakan ada anggota peneliti yang monitoring. Hal ini dilakukan untuk mengamati kegiatan pembelajaran, baik guru dalam menyampaikan materi maupun aktivitas siswa selama mengikuti pelajaran.

1) Monitoring guru

Monitoring terhadap guru meliputi: penampilan, kejelasan dalam menyampaikan materi, strategi dalam pembelajaran, metode dan media yang digunakan, serta pengelolaan kelas. Hasil monitoring penampilan guru baik; membuka kegiatan mengajar dan mengelola kelas cukup baik; mampu mengendalikan siswa sebanyak 4 dengan kemampuan dan karakteristik berbedabeda; guru mampu berinteraksi dengan siswa secara baik dan memberikan bimbingan satu persatu sesuai dengan kemampuannya, namun ada kelemahannya, yaitu alat/ papan panel yang digunakan dalam pembelajaran hanya 1 buah, sehingga siswa berebutan untuk memasang walaupun belum mendapat giliran.

2). Monitoring pada siswa

Pengamatan pada siswa meliputi: minat, perhatian, motivasi, aktivitas siswa selama dalam pembelajaran. Secara umum anak mempunyai minat, perhatian, motivasi yang baik dalam pembelajaran Iqro'. Sebagai bukti selama pembelajaran anak mengikutinya dengan senang dan penuh antusias, akan tetapi yang perlu dikendalikan sifat egois/ menang sendiri, yaitu selalu duluan membaca/ maju.

\section{d. Evaluasi Tindakan I}

Evaluasi tindakan dalam pembelajaran Iqro'dengan mengelompokkan huruf hijaiyah yang bentuknya sama dengan alat bantu karton yang bertulisan huruf hijaiyah dan papan panel siswa kelas III SLB C sesuai dengan silabus dan rencana pembelajaran. Berdasarkan hasil evaluasi Dari hasil evaluasi tindakan I dengan mengadakan tes menunjukkan hasil seperti terlihat pada tabel berikut. 
Data Kemampuan Membaca Iqro' pada siklus I

\begin{tabular}{|c|l|c|l|}
\hline No. & \multicolumn{1}{|c|}{ Nama } & Nilai & \multicolumn{1}{c|}{ Deskripsi kemampuan Membaca Iqro' } \\
\hline 1. & Afifah & 70 & $\begin{array}{l}\text { Siswa mampu melafadzkan huruf hijaiyah dengan cukup } \\
\text { bagus, cukup namun masih perlu bimbingan yang rutin. }\end{array}$ \\
\hline 2. & Eko & 60 & $\begin{array}{l}\text { Siswa memahami beberapa huruf hijaiyah, melafadzkanya, } \\
\text { tetapi kadang masih lupa membacannya karena terbiasa } \\
\text { menghafal tapi tidak faham tulisannya, sehingga perlu } \\
\text { bimbingan yang rutin. }\end{array}$ \\
\hline 3. & Fery & 70 & $\begin{array}{l}\text { Siswa mampu membaca huruf hijaiyah dengan bagus, } \\
\text { semangat namun perlu bimbingan dan latihan yang rutin. }\end{array}$ \\
\hline 4. & Rizki & 60 & $\begin{array}{l}\text { Siswa mampu melafadzkan huruf hijaiyah dengan cukup } \\
\text { bagus, tapi masih sering kebalik. }\end{array}$ \\
\hline
\end{tabular}

Grafik Kemampuan Membaca Iqro' pada siklus tindakan I

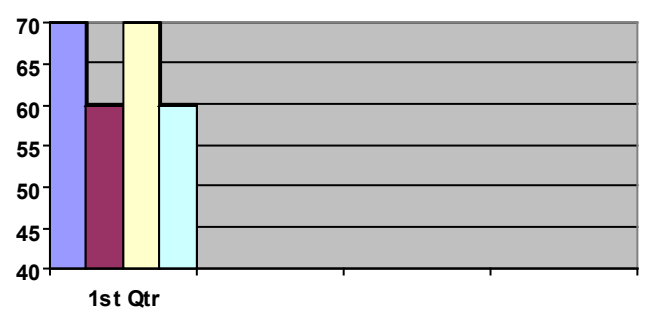

\section{e. Refleksi}

Berdasarkan evaluasi yang telah dilakukan pada tindakan I, peneliti dan kolaborator mencermati, belum memperoleh hasil yang maksimal, karena ada beberapa kendala yang dihadapi, sebagai berikut.

1) Siswa belum paham nama huruf hijaiyah dan pelafadzannya sehingga masih sering keliru dan kebalik.

2) Alat bantu yang gunakan hanya satu yang dipasang dipapan tulis, jadi siswa berebutan maju, walaupun guru menjelaskan yang membaca dan memasang huruf hijaiyah bergantian.

3) Dalam pembelajaran melafadzkan huruf hijaiyah pada tindakan I disertai huruf latinnya, sehingga siswa yang belum mampu membaca masih kesulitan apabila huruf latinnya dihilangkan/ Ketergantungan melihat huruf latinnya, karena anak terbiasa membaca dengan mengurutkan dan dimulai dari awal.

\section{Deskripsi Rencana Tindakan Siklus II}

Berdasarkan diskusi hasil refleksi, analisis data, dan evaluasi pada siklus I belum memperoleh hasil yang memuaskan, sehingga tim peneliti mengadakan modifikasi dalam pembelajaran. Perubahan ini dimaksudkan agar dalam pembelajaran dapat mencapai hasil yang maksimal, yaitu mampu membaca Iqro’ dengan benar. Dalam siklus ini terdiri dari empat pertemuan.

Adapun rencana tindakan yang akan dilaksanakan pada tindakan siklus II adalah sebagai berikut.

a. Dalam pembelajaran huruf hijaiyah langsung huruf Arabnya tanpa disertai huruf Latinnya, tidak perlu diurutkan dari huruf awal, tetapi disampaikan sesuai dengan kelompok huruf yang bentuknya 
sama. Hal ini akan melatih perhatian dan ingatan siswa.

b. Dalam pembelajaran materi Iqro' diulangulang sampai siswa paham. Setiap siswa membaca direkam setelah selesai siswa bisa mendengarkan suaranya sendiri dan mengetahui kesalahannya dan ini membuaat anak lebih senang dan semangat serta mengulanginnya sampai benar, baru meningkat ke materi selanjutnya, karena ciri anak tunagrahita adalah mudah lupa.

c. Dalam mempersiapkan alat bantu/karton dan papan panel yang bertuliskan huruf hijaiyah sebaiknya sejumlah siswa (4). Dengan demikian siswa tidak berebutan dan siswa diharapkan semua aktif, sehingga proses pembelajaran membaca Iqro' memperoleh hasil yang maksimal.

d. Agar motorik siswa terlatih dan dapat dimanfaatkan dengan optimal, maka selain anak mendengar, melihat, melafadzkan, dan memasang, maka siswa perlu dilatih untuk menulis materi yang telah disampaikan. Hal ini mengurangi kejenuhan siswa dan sangat membantu keberhasilan dalam pembelajaran Iqro'.

Berikut disajikan skema rencana tindakan siklus II.

\section{Keterangan bagan:}

Siswa kelas III SDLB C adalah subjek penelitian yang mengikuti pembelajaran Iqro' dengan strategi pengelompokan huruf hijaiyah yang sama bentuknya, dengan alat bantu karton dan papan panel yang bertulisan huruf hijaiyah. Jumlah alatnya disesuaikan dengan jumlah siswa.

Dalam pengenalan huruf hijaiyah tanpa dibantu huruf Latin. Kegiatan siswa adalah melafadzkan, memasang, dan menulis/ menyalin huruf hijaiyah.

Dengan adanya modifikasi dalam tindakan II ini, semua siswa lebih perhatian, semangat dan aktif dalam pembelajaran. Hal ini dapat dilihat dalam lampiran, saat siswa sama-sama aktif membaca dan memasang huruf hijaiyah.

\section{Deskripsi Pelaksanaan Tindakan Siklus} II

Pada tindakan siklus II dilaksanakan empat kali pertemuan.

a. Pertemuan pertama

Pertemuan pertama dilaksanakan tanggal 20-09-2016, di awal pembelajaran guru menyiapkan kelas. Pada pertemuan ini pembelajaran di masjid, agar anak tidak jenuh. Kemudian salah satu

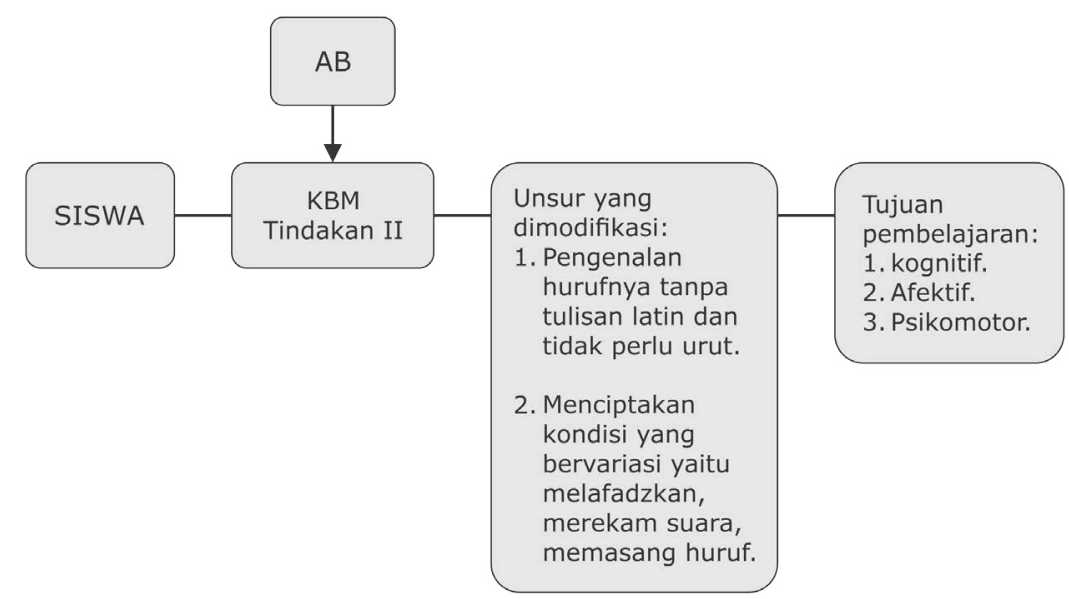

Gambar: Bagan Pelaksanaan kegiatan siklus Tindakan II 
siswa memimpin do'a sebelum belajar. Berdasarkan hasil yang diperoleh pada siklus I, siswa masih ada yang keliru dalam membaca huruf yang berbeda tetapi pelafadzannya hampir sama. Untuk itu pada pertemuan ini materinya berkaitan dengan huruf tersebut antara lain:

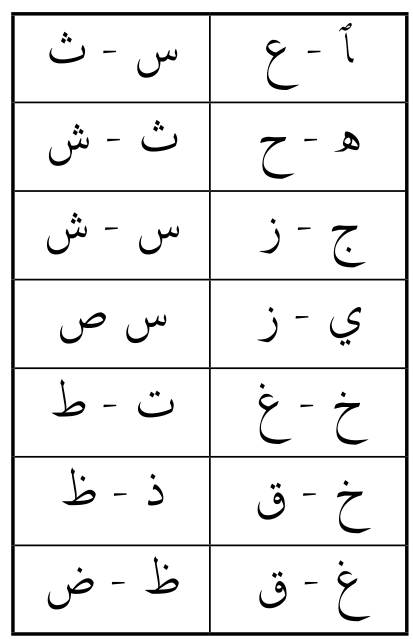

Guru memberi contoh pelafadzan huruf tersebut berulang-ulang, siswa menirukan bersama-sama. Kemudian satu persatu sambil memasang huruf tersebut pada papan panel, setelah selesai siswa menulis materi tersebut pada bukunya masing-masing. Pada pertemuan ini siswa belajar lebih semangat, di akhir pembelajaran siswa diberi tugas untuk membaca materi tersebut di rumah.

b. Pertemuan kedua

Pertemuan kedua dilaksanakan tanggal 27-09-2016. Pembelajaran diadakan di masjid, sebelum dimulai siswa tanpa diminta sudah mempersiapkan alat dan Iqro'. Setelah siswa siap di tempat duduknya masing-masing, salah satu siswa menyiapkan dan memimpin do'a sebelum belajar. Materi kali ini adalah membaca Iqro' jilid I. Semua siswa sudah membuka Iqro' yang sudah diberikan guru. Satu persatu membaca dengan disimak guru, bagi yang belum mendapat giliran ikut menyimak, ada yang membaca sendiri. Siswa pada pertemuan ini rata-rata sudah mampu membaca dengan benar dan cukup lancar, walaupun kemampuan siswa satu dengan yang lain berbeda. Di akhir pertemuan guru memberi tugas untuk membaca Iqro' materi selanjutnya, sehingga pada pertemuan yang akan datang anak sudah lebih lancar.

c. Pertemuan ketiga

Pada pertemuan ketiga dilaksakan tanggal 04-10-2016. Pembelajaran dilaksanakan di masjid, setelah do'a mau belajar dilafadzkan, seterusnya guru menugaskan siswa satu persatu untuk membaca Iqro' masing-masing dengan bimbingan guru. Bagi yang belum mendapat giliran ikut menyimak dan ada yang membaca sendiri,sesuai dengan materi masing- masing. Guru memberi reward bagi siswa yang mampu membaca dengan benar baik dengan sanjungan, suara anak direkam atau difoto satu persatu hasilnya dibagikan. Hal ini walaupun sederhana tetapi membuat anak semangat dan antusias dalam pembelajaran. Sebagai bukti siswa-siswa sudah hampir menyelesaikan Iqro' jilid I bahkan ada siswa yang sudah selesai dengan benar dan cukup lancar. Pada akhir pembelajaran siswa tetap ditugaskan untuk membaca di rumah. Hal ini juga disampaikan kepada orang tua/ wali murid karena tanpa kerja sama yang baik pembelajaran tidak akan berhasil. 


\section{d. Pertemuan keempat}

Pertemuan keempat dilaksanakan 10-11-2016, guru mengkondisikan siswa kemudian salah satu siswa memimpin do'a sebelum belajar. Sebelum masuk ke materi selanjutnya, siswa satu persatu ditugaskan membaca materi minggu lalu. Setelah semua mendapat giliran dan siswa sudah lancar dalam membaca, materi dilanjutkan. Siswa membaca Iqro' masing-masing dengan bimbingan guru. Pada pertemuan keempat ini siswa sudah mampu menyelesaikan Iqro' I dengan benar dan cukup lancar. Dan ada dua siswa yang sudah mulai jilid II, yaitu Afifah dan Ferry.

\section{Deskripsi Hasil Monitoring}

Monitoring pada tindakan siklus II dilakukan oleh anggota peneliti yang terdiri dari satu orang guru. Hal ini dilakukan untuk mengetahui kemajuan kegiatan pembelajaran. Monitoring dalam kegiatan ini terdiri dari dua aspek yaitu:

a. Monitoring kegiatan guru

Monitoring terhadap guru pada tindakan siklus II berkaitan dengan: penampilan guru, keaktifan guru, kreativitas guru dan kemampuan guru dalam mengelola kelas. Hasil monitoring yang berkaitan dengan guru memperoleh hasil yang baik. Dalam setiap pertemuan pada tindakan siklus II sudah menerapkan hasil refleksi yang telah dilakukan pada tindakan I, antara lain:

1) Dalam pembelajaran, selanjutnya guru membagi karton dan papan panel yang bertulisan huruf hijaiyah sesuai materi yang akan diajarkan. Siswa melafadzkan dan memasang hurufnya sesuai dengan instruksi peneliti, dan peneliti memberi bimbingan siswa yang belum mampu. Dalam mengenalkan huruf hijaiyah tanpa dibantu dengan huruf latinnya, dengan mengulang-ulang sampai paham betul, membacanya sesuai kelompok hurufnya (tidak perlu diurutkan), sehingga anak tidak sekadar menghafal tetapi mampu melafadzkan materi yang diajarkan/ disampaikan.

2) Alatbantuyang digunakan, yaitukarton dan papan panel yang bertuliskan huruf hijaiyah, tidak hanya satu, tetapi jumlahnya disesuaikan dengan jumlah siswa (4), sehingga semua siswa aktif tidak saling berebutan dan mengganggu temannya. Dengan strategi dan alat yang dipersiapkan secara lengkap diharapkan pada tindakan II, pembelajaran Iqro' akan lebih optimal, yaitu siswa mampu menyelesaikan Iqro' I dengan benar.

3) Agar siswa tidak mudah bosan, kegiatan siswa menulis atau menyalin materi yang sudah dibaca dan dipasang, hal ini akan membantu melatih motorik halus anak dan kelancaran pembelajaran Iqro'.

4) Setelah pembelajaran selesai, langkah selanjutnya adalah mengadakan evaluasi, yaitu berupa tes formatif baik lisan, tertulis maupun perbuatan. Dengan evaluasi dapat diketahui hasil yang akan dicapai mencakup tiga aspek, yaitu aspek kognitif/ pemahaman dan pengetahuan membaca huruf hijaiyah/ Iqro'; aspek afektif/ perasaan senang, nyaman, semangat, aktif saat berlangsungnya pembelajaran; aspek psikomotor, yaitu kemampuan 
anak untuk menunjuk dan memasang serta membaca huruf hijiyah/ Iqro' dan membiasakan untuk membaca Iqro'. Sebelum mengadakan evaluasi peneliti terlebih dahulu membuat skala penilaian yang disesuaikan dengan kurikulum.

b. Monitoring pada siswa

Monitoring siswa pada tindakan siklus II berkaitan dengan: minat, motivasi, aktivitas, perhatian siswa.Yang berkaitan dengan tersebut di atas hasilnya baik. Karena dalam pembelajaran anak merasa senang, nyaman bahkan sangat antusias. Hal ini juga dibuktikan dalam hasil yang diperoleh yaitu siswa mampu membaca Iqro' dengan benar.

\section{Hasil Evaluasi Tindakan II}

Dalam tindakan II ini pembelajarannya lebih kondusif siswa lebih perhatian, semangat, dan hasil yang diperolehpun meningkat. Hal ini dapat dilihat dari hasil evaluasi baik aspek kognitif, afekktif maupun psikomotor, yaitu siswa lebih mampu membaca huruf hijaiyah secara acak/ membaca kata sederhana dan sebagian siswa mampu menyelesaikan Iqro jilid I. Hasil ini dapat diketahui dari hasil tes akhir baik secara lisan, tertulis maupun perbuatan.

Berdasarkan evaluasi tindakan II hasil yang diperoleh siswa dalam kemampuan membaca Iqro' adalah sebagai berikut.

Tabel 3

\section{Data Kemampuan Membaca Iqro'} Siswa kelas III SLB C Bhakti Kencana Sleman Yogyakarta (Pada siklus tindakan II)

\begin{tabular}{|c|l|c|l|}
\hline No. & \multicolumn{1}{|c|}{ Nama } & Nilai & \multicolumn{1}{c|}{ Deskripsi kemampuan Membaca Iqro' } \\
\hline 1. & Afifah & 90 & $\begin{array}{l}\text { Siswa mampu melafadzkan huruf hijaiyah secara acak } \\
\text { dengan cukup bagus, dan menyelesaikan Iqro' jilid I. }\end{array}$ \\
\hline 2. & Eko & 60 & $\begin{array}{l}\text { Siswa memahami huruf hijaiyah, melafadzkanya, dan } \\
\text { membaca kata sederhana, dan menyelesaikan Iqro' jilid I. }\end{array}$ \\
\hline 3. & Fery & 70 & $\begin{array}{l}\text { Siswa mampu membaca huruf hijaiyah secara acak dan } \\
\text { penuh semangat dengan bagus, dan mampu menyelesaikan } \\
\text { Iqro' jilid I. }\end{array}$ \\
\hline 4. & Rizki & 60 & $\begin{array}{l}\text { Siswa mampu melafadzkan huruf hijaiyah dengan cukup } \\
\text { bagus, dan mampu menyelesaikan Iqro' jilid I. }\end{array}$ \\
\hline
\end{tabular}

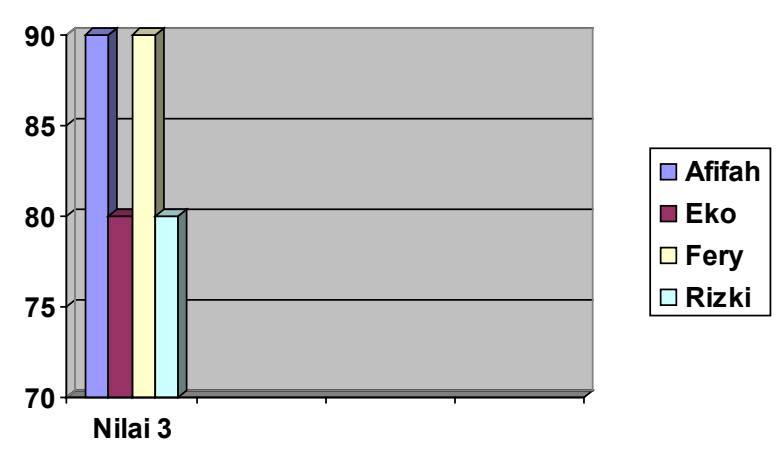

Grafik kemampuan membaca Iqro' pada siklus tindakan II 
Berdasarkan grafik di atas, dapat diketahui tentang keberhasilan dalam pembelajaran Iqro'. Buktinya adalah peningkatan kemampuan siswa dalam membaca huruf hijaiyah/ Iqro' pada siswa kelas III SDLB C Bhakti Kencana Yogyakarta. Hasil yang tampak adalah siswa sudah mampu membaca huruf hijaiyah secara acak dengan benar, bahkan mampu menyelesaikan Iqro' jilid I.

\section{Pemantuan dan Evaluasi}

Peneliti dan kolabolator telah melakukan pemantauan dan evaluasi terhadap jalannya pemberian tindakan.

a. Keberhasilan proses

Keberhasilan proses dinyatakan siswa pada saat wawancara bahwa pembelajaran Iqro' dengan cara pengelompokan huruf yang bentuknya sama dengan menggunakan alat bantu tulisan pada karton dan papan panel bertulisan huruf hijaiyah, siswa merasa senang. Sebagai bukti dalam pembelajaran siswa lebih perhatian, semangat, dan aktif. Sebelumnya dalam pembelajaran Iqro' menggunakan metode mengenal dan melafadzkan huruf hijaiyah secara urut/ dari huruf paling awal, dengan melihat tulisan huruf hijaiyah di papan tulis, sehingga anak mampu menghafalnya tetapi tidak memahami hurufnya.

b. Keberhasilan produk

Berdasarkan hasil pengamatan di lapangan dapat diketahui bahwa semua siswa mengikuti pembelajaran Iqro' dengan baik. Walaupun pada awalnya siswa agak sulit melafadzkan dan membaca huruf hijaiyah serta konsep hurufnya sulit dipahami, akan tetapi masalah tersebut dapat diatasi dengan strategi pengelompokan huruf hijaiyah yang bentuknya sama dengan menggunakan karton dan papan panel yang bertulisan huruf hijaiyah, sehingga yang selama ini anak mudah bosan, materi yang diberikan mudah lupa, pasif, anak berubah lebih aktif, semangat sehingga pembelajaran Iqro' memperoleh hasil dengan baik dan optimal. Peningkatan kemampuan membaca huruf hijaiyah atau Iqro' dari kemampuan awal/ sebelum diberi tindakan, setelah tindakan I dan II tampak pada grafik di bawah ini.

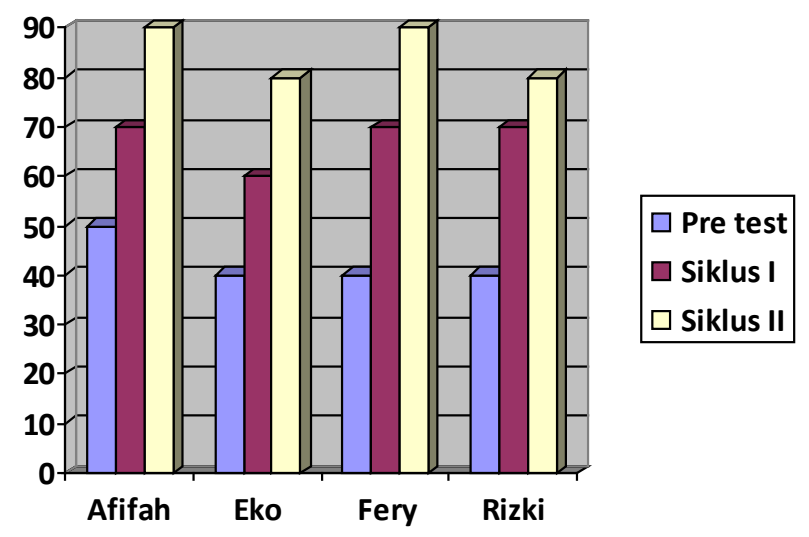

Grafik perubahan kemampuan membaca Iqro' sebelum ada tindakan, setelah siklus tindakan I dan II

Keterangan:

Garis bawah : Sebelum tindakan

Garis tengah : Setelah siklus Tindakan I

Garis Atas : Setelah siklus Tindakan I

\section{Refleksi Tindakan Siklus II}

Pelaksanaan pembelajaran membaca Iqro' dengan strategi pengidentifikasian huruf hijaiyah yang bentuknya sama pada siklus II telah sesuai dengan perancanaan yang telah disusun berdasarkan refleksi tindakan I. Selama pembelajaran sampai pada siklus II dapat dikatakan mengalami peningkatan baik berkaitan dengan respon, 
motivasi, perhatian maupun keantusiasannya. Pelaksanaan pembelajaran Iqro' pada siklus II ini dikatakan berhasil, hal ini dibuktikan dalam kemampuan siswa kelas III SDLB C dalam membaca Iqro'.

\section{KESIMPULAN}

Berdasarkan pengamatan selama pembelajaran Iqro' siswa tunagrahita SDLB kelas III, dengan strategi pengidentifikasian huruf hijaiyah yang bentuknya sama disertai alat bantu yang menarik, akan menjadikan perubahan yang positif yaitu anak merasa senang karena ada unsur bermainnya sehingga anak tidak mudah bosan, yang selanjutnya akan berpengaruh terhadap peningkatan keberhasilan membaca Iqro'.

Berdasarkan hasil wawancara dengan siswa, dengan strategi dan alat bantu yang digunakan dalam pembelajaran Iqro' di atas, anak merasa tertarik, senang, dan tidak bosan, Karena ciri anak tunagrahita ringan di antarannya sulit berPikir abstrak dan mudah bosan.

Pengenalan dan mampu membaca huruf hijaiyah adalah bagian dari kurikulum pendidikan agama Islam. Dalam kurikulum tersebut anak dharapkan mampu mengenal dan membaca huruf hijaiyah/ Iqro' dengan benar. Kemampuan membaca Iqro' ini diharapkan akan membantu dalam pembelajaran menghafal surat- urat pendek, do'a sehari-hari, dan materi lainnya., yang tercantum dalam kurikulum, tentunya juga disesuaikan dengan kondisi dan kemampuan siswa.

Dalam pembelajaran huruf hijaiyah yang pertama dilakukan adalah pengenalan huruf dengan pengelompokkan huruf hijaiyah sesuai dengan bentuknya, dengan karton dan papan panel yang bertulisan huruf hijaiyah, memberi contoh pelafadzan dengan menunjukkan bentuk huruf dan tandanya, dengan mengacak, membaca dan melafadzkan kata sederhana, menyelesaikan Iqro' jilid I. Evaluasi yang digunakan untuk mengetahui kemampuan membaca huruf hijaiyah/ Iqro' siswa kelas III SDLB C Bhakti Kencana adalah menentukan indikator dan tujuan yang ingin dicapai sesuai dengan silabus yang sudah dibuat sebelumnya, juga kriteria penilaiannya (lihat lampiran). Dalam penilaiannya memperhatikan tiga ranah/ aspek, yaitu kognitif, afektif, psikomotor.

Adapun hasil penelitian tindakan I, kemampuan membaca Iqro' belum optimal karena siswa belum paham konsep huruf, kebiasaan menghafalkan kurang memperhatikan hurufnya, terbatasnnya alat yang digunakan, sehingga anak saling berebut kurang konsentrasi. Karena dalam tindakan I hasilnya belum optimal maka peneliti mengadakan modifikasi dan variasi pada tindakan II antara lain: dalam pembelajaran huruf hijaiyah tidak selalu disertai huruf Latinnya/ hanya dalam pengenalan huruf permulaan saja dan dalam pengenalan hurufnya sampai anak paham baru pindah ke materi berikutnya. Hal ini agar anak lebih perhatian, tidak hanya menerka atau hafalan saja tetapi memahami betul huruf yang dibaca. Juga menyediakan alat bantu sesuai jumlah siswa dan dibuat yang menarik/ warna warni sesuai dengan kelompok hurufnya, siswa menulis materi yang sudah dipelajari, sehingga motorik siswa akan terlatih dengan baik.

Berdasarkan data di lapangan, maka dalam tindakan II perlu modifikasi dan variasi strategi identifikasi dan alat bantu yang menarik dan efektif untuk meningkatkan kemampuan membaca Iqro' siswa kelas III SLB C Bhakti Kencana Yogyakarta. Hal ini dapat dilihat berdasarkan hasil evaluasi yang dilakukan 
setiap selesai pembelajaran, siswa mengalami peningkatan. Hal ini dapat dilihat pada tabel 3 dan grafik setelah tindakan II, yaitu anak mampu membaca huruf hijaiyah, menulis dan mampu menyelesaikan Iqro' jilid I benar.

Dengan demikian setelah dilakukan beberapa tindakan bahwa dalam pembelajaran Iqro' dengan strategi pengelompokan huruf hijaiyah disertai alat yang berupa karton dan papan panel yang bertulisan huruf hijaiyah pada siswa kelas III SLB C Bhakti Kencana Yogyakarta disimpulkan sebagai berikut.

1. Adannya perubahan yang positif pada siswa kelas III SDLB C, yaitu dalam pembelajaran Iqro' siswa merasa senang, aktif, dan antusias, karena siswa tidak hanya melihat, mendengar, melafadzkan, memasang huruf hijaiyah tetapi juga menyalin/ menulis materi yang telah disampaikan.

2. Dalam pembelajaran Iqro' terjadi adannya peningkatan. Hal ini dapat diketahui dari hasil evaluasi, bahwa siswa mampu mengenal, melafadzkan, membaca huruf hijaiyah dan menyelesaikan Iqro' jilid I dengan lancar, bahkan ada dua siswa yang sudah mulai Iqro' II.

\section{E. DAFTAR PUSTAKA}

Arikunto, Suharsimi. (2012), Prosedur Penelitian Suatu Pendekatan Praktik, Jakarta: PT. Bina Aksara.

Arsyad, Azhar. (2003), Media Pembelajaran, Jakarta.

Cholik, M. (2010), "Prosedur Pelaksaan PTK", Diklat Teknis PTK Guru SLB Di Lembang Bandung. . (2006), "Penulisan Laporan PTK", Diklat Teknis PTK Guru SLB, Di Lembang, Bandung.
. (2006), "Penulisan Artikel Hasil Penelitian”, Diklat Teknis PTK Gur5u SLB, Di Lembang Bandung.

Depdiknas. (2005), Penelitian tindakan Kelas, Jakarta

Depdiknas. (2003), Media Pembelajaran, Jakarta.

Depdikbud. (2001), Penelitian Tindakan Kelas, Jakarta.

Djanar, Syaiful Bahri. (2005), Guru dan Anak Didik Dalam Interraktif, Jakarta: Andi Offset.

Elliot, John. (2002), Action Research for Educational Change, Philadelpia: Open University Press.

Humam, KH. As'ad. (2001). Pengelolaan, Pembinaan dan Pengembangan Membaca, Menulis, Memahami AlQur'an, Jakarta.

Muharjito. (2008), "Model- Model PTK", Diklat Teknis PTK Guru SLB, Di Lembang Bandung.

Natawijaya, Rahman. (1996), Penelitian Bagi Guru Pendidikan Luar Biasa, Jakarta.

Tirtonegoro, Sutratinah. (2001), Metode Khusus Pengajaran Anak Tunagrahita, Yogyakarta: FIP IKIP.

$$
\text { (2001), }
$$

Orthopedagogik Tunagrahita, Yogyakarta: FIP IKIP.

Sanjaya, Wina. (2006), Strategi Pembelajaran, Bandung.

Suwarsih Madya. (2007), Seri Metodologi Penelitian Tindakan, Yogyakarta: Lembaga Penelitian IKIP. 